\title{
Akcijski planovi protiv nepismenosti u Hrvatskoj od 1945. do 1970-ih
}

TOMISLAV ANIĆ

Hrvatsko katoličko sveučilište, Odjel za povijest

Zagreb, Hrvatska

tomislav.anic@unicath.hr

VJERA BRKOVIĆ

Hrvatsko katoličko sveučilište, Odjel za povijest

Zagreb, Hrvatska

vjera.brkovic@unicath.hr

U kontekstu političkih, gospodarskih i društvenih promjena sredinom XX. stoljeća sustavno se ostvaruju temeljni ciljevi Komunističke partije Jugoslavije na svim razinama te dolazi do strukturnih promjena u društvu. Zadane promjene može se pratiti i preko mjera poduzetih za smanjenje broja nepismenih, što je izravno proizlazilo iz potrebe rješavanja temeljnih društvenih i gospodarskih problema.

U radu se problematizira borba protiv nepismenosti u Hrvatskoj nakon Drugoga svjetskog rata. Akcijski planovi opismenjavanja stanovništva koje su sustavno provodili državni organi pokazuju da se korjenito mijenjala slika društva. Odgojno-obrazovne teme i povijest školstva XX. stoljeća u hrvatskoj historiografiji, uz određene iznimke, neistražene su kao primjerice u historiografiji XIX. stoljeća.

Autori su analizom izvora i literature uspostavili tri faze odgojno-obrazovnih promjena. U ovom će se radu pratiti problem rješavanja nepismenosti preko promjena odgojno-obrazovnoga sustava i akcijskih planova opismenjavanja od 1945. do završne faze 1974., kada je donesena odluka o osnivanju Komisije za borbu protiv nepismenosti.

Namjera je ovim radom doprinijeti istraživanju povijesti obrazovanja u hrvatskoj historiografiji. 
Ključne riječi: Hrvatska; XX. stoljeće; socijalizam; nepismenost; opismenjavanje; odgojno-obrazovni sustav

\section{Uvod}

Nakon završetka Drugoga svjetskog rata Komunistička partija Jugoslavije (KPJ) mogla je prijeći iz međuratnoga, ponajviše teorijskog razdoblja u novo provedbeno razdoblje stvaranja društvenopolitičkoga okvira. Izgradnja socijalističkoga uređenja zahtijevala je ponajprije uvođenje sustava narodne vlasti, federativnoga državnog uređenja i rukovodeći položaj KPJ u svim društvenim organizacijama. Jedan od važnih segmenata pritom je bilo rješavanje problema nepismenosti.

Prva veća i sustavna aktivnost opismenjavanja koja je prethodila razdoblju po završetku Drugoga svjetskog rata vezana je uz Seljačku slogu, kulturno-prosvjetnu organizaciju Hrvatske seljačke stranke osnovanu 1925. godine. ${ }^{1}$ Djelatnošću poučavatelja Odsjeka za osnovne škole i analfabetske tečajeve Prosvjetnoga odjela Zemaljskoga antifašističkog vijeća narodnog oslobođenja Hrvatske na teritoriju koji je od 1944. bio pod partizanskom ingerencijom započeli su tečajevi opismenjavanja. Nakon što su komunisti 1945. preuzeli vlast ta se kampanja proširila na čitavo područje Narodne Republike Hrvatske, odnosno Demokratske Federativne Jugoslavije / Federativne Narodne Republike Jugoslavije (FNRJ). ${ }^{2}$

Problematiku nepismenosti u Hrvatskoj od 1945. do 1970-ih na temelju uvida u izvore i literaturu s obzirom na odgojno-obrazovne promjene podijelili smo u tri faze. Prva obuhvaća razdoblje od 1945. do pedesetih godina, druga šezdesete i treća sedamdesete godine XX. stoljeća. Nakon uvođenja socijalističkoga samoupravljanja njegova refleksija može se pratiti i u promjenama u obrazovanju, što će u ovom slučaju biti vidljivo u drugoj i trećoj fazi. U prve dvije faze promjene su se odnosile isključivo na smanjivanje broja nepismenih, osnovnoškolsko obrazovanje i afirmaciju dotad nerazvijenoga predškolskog odgoja u obrazovnom sustavu, a u trećoj fazi promjene će zahvatiti srednjoškolsko i visoko obrazovanje. ${ }^{3}$

Obrazovne promjene započele su 1945., kada je u rujnu donijet Zakon o obaveznom sedmogodišnjem školovanju. Preobrazba je trebala zahvatiti odgoj i obrazovanje odraslih radi smanjivanja broja nepismenih. Stoga treba istaknuti da je u godinama neposredno nakon Drugoga svjetskog rata, ovisno o izvorima, broj nepismenih varirao između 350000 i 522112 od ukupno

\footnotetext{
LEČEK, „Suradnja HKD Napredak i Seljačke sloge”, 1101.

OGRIZOVIĆ, „Školstvo i prosvjeta u Hrvatskoj”, 233.

POTKONJAK, Kuda ide srednje obrazovanje, 46.
} 
3785455 stanovnika. ${ }^{4}$ Prema jednoj od analiza Agitaciono-propagandnoga odjeljenja (Agitprop), središnjega tijela čiji je jedan od glavnih zadataka bilo oblikovanje javnoga mišljenja poratne Hrvatske/Jugoslavije, u svibnju 1947. čak je petina svih stanovnika Narodne Republike Hrvatske starijih od deset godina bila nepismena. ${ }^{5}$

U sklopu mjera za smanjivanje broja nepismenih, na 3. plenumu KPJ, održanom u Beogradu 29. i 30. prosinca 1949., a posvećenom školstvu, među ostalim se raspravljalo i o mogućnostima produživanja obveznoga osnovnog školovanja na osam godina. ${ }^{6}$ Zaključci o promjenama potvrđeni su na 4 . plenumu Centralnoga komiteta Komunističke partije Hrvatske, koji je zasjedao 17. travnja 1950. godine. Plenum je potvrdio potrebu uvođenja samoupravljanja u odgojno-obrazovni sustav i najavio postupno uvođenje osmogodišnjega školovanja. ${ }^{7}$

Sustavno opismenjavanje nepismenih ljudi na tečajevima za nepismene bio je jedan od najvećih kulturnih dometa, kako se to naglašavalo u propagandne svrhe. Treba istaknuti da su u tom razdoblju u svim sadržajima i metodama odgoja i obrazovanja obavljene važne izmjene novim nastavnim planovima i programima, koji su zasnovani na temeljima marksizma i socijalizma s ciljem idejne društveno-političke preobrazbe.

Budući da je prema Ustavnom zakonu iz 1953. institucionalizirano samoupravljanje, njegovim je temeljnim načelima određeno da su sva sredstva za proizvodnju u društvenom vlasništvu te da proizvođači sami upravljaju gospodarstvom. ${ }^{8}$ Tu logiku slijedile su i promjene u odgojno-obrazovnom sustavu. Posebno su važni pomaci u razvoju mreže osnovnih škola, kao i sama zakonska obveza osnovnoškolskoga obrazovanja. ${ }^{9}$ Konkretne promjene nastupaju s donošenjem Općega zakona o školstvu 1958. godine. ${ }^{10}$ Zakonom se uvodi osmogodišnje osnovnoškolsko obrazovanje, razvija nerazvijeno predškolsko obrazovanje i primjenjuju se pojačane mjere borbe protiv nepismenosti s programima opismenjavanja odraslih. ${ }^{11}$

\footnotetext{
$4 \quad$ STIPETIĆ, „Pismenost i razvoj”, 2484.

SPEHNJAK, Javnost i propaganda, 211.

ĐORĐEVIĆ, POTKONJAK, Pedagogija, 136.

ZANINOVIĆ, Opća povijest pedagogije, 321.

BILANDŽIĆ, Hrvatska moderna povijest, 324-325.

ĐORĐEVIĆ, POTKONJAK, Pedagogija, 136-137.

Prosvjetni vjesnik (Zagreb), 1958., br. 7, 66-79.

Isto. U čl. 34. stoji da osoba starija od 15 godina koja nije završila srednju školu može završiti školovanje izvanrednim polaganjem, a čl. 79. navodi da je jedan od osnovnih zadataka obrazovanja odraslih i stručnoga usavršavanja pružanje pismenosti.
} 
Stvaranje socijalističkoga poretka

\section{„U nepismenoj zemlji nema socijalizma”}

Suzbijanje nepismenosti bilo je izrazito važno za izgradnju novoga sustava, prije svega zbog velike potrebe za kvalificiranom radnom snagom na kojoj se temeljio čitav budući razvoj države. Za vrijeme prve Jugoslavije obrazovni se sustav nije bazirao na školovanju stručnoga kadra u srednjim stručnim školama, nego je dominantnu ulogu u školstvu imalo opće obrazovanje u obliku gimnazija. Tehnička inteligencija u pravilu je dolazila iz redova građanstva (iz redova radništva bilo je $3 \%$ studenata) i samo je ona zajedno s visokokvalificiranim kadrovima mogla pokrenuti privredu nakon rata. ${ }^{12}$ No najveći je problem bilo to što društvo koje se stvaralo nije prihvaćalo vrijednosni sustav vremena koje je formiralo tehničku inteligenciju i visokokvalificirane radnike. Prema njima je novi poredak bio izrazito nepovjerljiv, u prvom redu zbog podrijetla, načina života i odvojenosti od partizanskoga pokreta. Forsiranje industrijalizacije, točnije izlazak iz gospodarske zaostalosti bio je glavni cilj KPJ i upravo se zato moralo prihvatiti veliki dio stručnjaka koji prema svojem političkom opredjeljenju nisu ni izbliza odgovarali proklamiranim ciljevima Partije. Da bi se osigurala u odnosu na nepoćudni kadar, vlast je u želji za izgradnjom državnoga sektora i industrije „punim tempom” taj problem, koji je očito bio prilično opterećenje, rješavala tako da je na rukovodeće položaje postavljala komuniste, a za njihove pomoćnike stručnjake. ${ }^{13} \mathrm{Na}$ taj je problem i njegovo rješenje na konferenciji Privrednoga savjeta Vlade FNRJ 23. srpnja 1946. u svojem referatu upozorio njegov predsjednik, ujedno ministar industrije Boris Kidrič: „Stvar je onda tog komuniste da ga pravilno iskoristi [stručnjaka nekomunista, op. a.], da ne sektaši i da ga postepeno pridobije za našu stvar i tako ga prevede na nov mentalitet." 14

Problem pismenosti bio je usko povezan s uspjehom, boljim životom i napretkom cjelokupne zajednice. Nepoznavanje vještine čitanja i pisanja zaposlenika u industriji trebalo je svesti na najmanju moguću mjeru jer je upravo radništvo trebalo ostvariti ideju revolucije. Kriterij o tome što je pismenost mijenjao se. ${ }^{15}$ Razumijevanje pojma i definicije pismenosti/nepismenosti s obzirom na povijest možemo podijeliti na period do 1950., kada je ona podrazumijevala alfabetsku pismenost, a nakon 1950. govori se o funkcionalnoj pismenosti kao širem pojmu - biti pismen znači moći se sporazumijevati, tj.

\footnotetext{
PETRANOVIĆ, Politička i ekonomska osnova narodne vlasti, 312.

ZEČEVIĆ, LEKIĆ, Privredna politika Vlade FNRJ, 108.

Isto, 108.

RADELIĆ, Hrvatska u Jugoslaviji, 321.
} 
znati čitati, pisati, slušati i govoriti. ${ }^{16}$ Definicija nepismenosti i polupismenosti može se razjasniti na temelju proučavanih dokumenata. Nepismenost je obuhvaćala sve one koji su bez ikakve školske spreme, a polupismenost one koji imaju jedan do tri razreda osnovne škole. O tim kriterijima ovisio je i konačni broj nepismenih vidljiv u popisima stanovništva. Isticana Lenjinova teza da „u nepismenoj zemlji nema socijalizma” bila je misao vodilja cjelokupne kampanje opismenjavanja. Upravo se tim putem išlo neposredno nakon završetka rata, prije svega u propagandnom smislu: „Prosvijećenost, stručna sposobnost, potpuna klasna svijest širokih radnih masa ne može se zamisliti bez osnovnog temelja znanja, bez pismenosti naroda." ${ }^{17}$ Mjere opismenjavanja odnosile su se na radno stanovništvo, a trebale su omogućiti nastavak školovanja do potpunoga osnovnog obrazovanja. ${ }^{18}$ Opismenjavanje, ali i doškolovanje, bilo je prioritet državnih organa zaduženih za izradu akcijskoga plana. Da bi se stvorila uporišta za sustavnu borbu, svaka republika imala je isti zadatak: sustavnim mjerama potpuno opismeniti stanovništvo. Radništvo je trebalo postati pokretačka snaga cjelokupnoga razvoja. Prema popisu Saveznoga zavoda za planiranje, od svibnja do prosinca 1945. u Jugoslaviji je u industriji bilo zaposleno 393299 radnika. Veliki je problem bio i to što je ionako nedostatna radna snaga tijekom rata prorijeđena za otprilike $40 \%$ stručnjaka. Nedostatak stručnih kadrova po pojedinim industrijskim granama bio je iznimno kritičan, posebno uzme li se u obzir ambicioznost vlasti. Tako je u metalnoj industriji nedostajalo 4000 stručnjaka, u prehrambenoj industriji 580, u tekstilnoj industriji 830, u kožarskoj 470 i u kemijskoj 900 stručnjaka, a geologa je nedostajalo petnaest puta više nego što ih je u to vrijeme bilo. ${ }^{19}$ Kampanja opismenjavanja dovodila se u usku vezu s uspješnim ostvarenjem petogodišnjega plana (zakonom određen plan razvoja jugoslavenske ekonomije). $\mathrm{Na}$ taj su način trebali biti osposobljeni kadrovi za veću produktivnost rada. Prema petogodišnjem planu, trebalo je potpuno likvidirati nepismenost. ${ }^{20}$

\section{Nepismenost - neprijateljica radničke klase}

Nastavljajući se na međuratne tečajeve opismenjavanja, i KPJ je u svojim programatskim spisima kao jedan od važnih elemenata razvoja društva naglašavala upravo eliminaciju nepismenosti, što je bilo očito na osnivačkom

\footnotetext{
DIJANOŠIĆ, „Funkcionalna pismenost”, 23.

„Na borbu protiv nepismenosti”, Glas rada (Zagreb), 6. 12. 1946., 4.

UJAKOVIĆ, ABC za odrasle, 42-45.

„Na borbu protiv nepismenosti”, Glas rada, 6. 12. 1946., 4.

„Zakon o petogodišnjem planu. Razvitak narodne privrede FNRJ 1947-1952.”, Službeni list FNRJ (Beograd), 1947., 235.
} 
kongresu Narodnoga fronta Jugoslavije 7. kolovoza 1945. godine. ${ }^{21}$ Iz pisanih izvora, i novinskih i arhivskih, uočava se da je problem nepismenosti radnika uočen odmah po završetku rata, no veća mu je pozornost posvećena dvije godine poslije, kad je Odjel za narodno prosvjećivanje pri Ministarstvu prosvjete počeo s aktivnostima preko referada za likvidaciju nepismenosti. ${ }^{22}$ Upravo su na opismenjavanje stavili naglasak novinari Glasa rada: „Kako će takvi drugovi znati da gospodare svojim strojem, da ga usavršavaju, da ga prisile na što veću proizvodnju?” a čitav je proces trebao dovesti do „opće kulturnog izdizanja svakog pojedinog radnika i radničke klase kao cjeline". ${ }^{23}$ Ministarstvo prosvjete, potpomognuto sindikalnim organizacijama, imalo je 1945. razvijenu strategiju za borbu protiv nepismenosti. Prema tom su planu sve sindikalne podružnice, ustanove ili poduzeća preko svojih kulturno-prosvjetnih odbora ili članova zaduženih za kulturno-prosvjetni rad trebali popisati sve nepismene i slabo pismene, kao i članove njihovih obitelji. Nakon prikupljanja podataka sljedeća instanca bila je prijava mjesnoj organizaciji Saveza prosvjetnih radnika ili, ako ona nije postojala, mjesnim prosvjetnim vlastima da bi se osigurao voditelj tečaja. Mogućnost za izvedbu tečajeva bila je dvojaka. U velikim gradovima mogli su se organizirati unutar pojedinoga odjeljenja poduzeća ili u sindikalnim podružnicama. Voditelj je u tom slučaju morao napraviti raspored prema obvezama radnika. U manjim je mjestima i manjim sindikalnim podružnicama analfabetski tečaj obuhvaćao radnike više struka ili sve radništvo, pa i, ovisno o broju, sve nepismeno stanovništvo. Takav oblik pouke predviđao je dvadesetak polaznika po tečaju od sto radnih sati u trajanju od četiri mjeseca $(2 \times 3$ ili $3 \times 2$ sata tjedno izvan radnoga vremena). $Z$ a te je tečajeve predviđeno, osim savladavanja osnovnoga znanja pisanja, čitanja i računanja, i stjecanje elementarnoga znanja iz zemljopisa, povijesti i prirodnih znanosti. Veliki problem bilo je pomanjkanje kadrova sposobnih za provedbu tečajeva, prije svega učitelja i nastavnika. Tom se problemu pokušalo doskočiti organiziranjem kratkih pomoćnih tečajeva za voditelje analfabetskih tečajeva, koji su bili predviđeni za aktiviste Narodnoga fronta i njegovih organizacija, Ujedinjenoga saveza antifašističke omladine Hrvatske, Antifašističke fronte žena, Jedinstvenih sindikata radnika i namještenika Jugoslavije te naposljetku sve pismene radnike. Voditelji su prema planu bili učitelji stručnjaci. Novčana stimulacija za voditelje tečajeva nije bila moguća iako se radilo o honorarnom prekovremenom radu, čega su inicijatori programa bili svjesni. Shodno tomu prvenstveno se u pozivu na sudjelovanje učitelja stručnjaka u tečajevima apeliralo na njihovo rodoljublje, no s naznakom da će se u perspektivi otvoriti

\footnotetext{
${ }^{21}$ PETRANOVIĆ, „Osnivački kongres Narodnog fronta Jugoslavije”, 14.

22 SPEHNJAK, Javnost i propaganda, 208.

23 „Suzbijajmo nepismenost”, Glas rada, 12. 10. 1945., 4.
} 
mogućnost redovitoga plaćanja vođenja tečajeva. Tečajeve opismenjavanja vodili su u najvećem broju slučajeva nestručni poučavatelji, a tek manjim dijelom učitelji zbog opterećenja drugim prosvjetnim zadacima. Iza termina nestručni poučavatelji krili su se svi oni koji su održavali nastavu bez potrebne stručne spreme, a to su pretežno bili školovani ili barem pismeni omladinci. ${ }^{24}$

\section{Uloga propagande u opismenjavanju}

Za omasovljenje pismenosti preko tečajeva primijenjena je intenzivna propaganda, kao i natjecanje polaznika u napredovanju na radu te voditelja prema uspjehu njihovih polaznika. Propaganda se tako provodila na plenumima, sastancima sindikalnih organizacija, zidnim novinama, plakatima, u razgovorima s nepismenim radnicama i radnicima i tiskovinama svih vrsta (dnevnim, tjednim, mjesečnim). Plan je bio prije svega usmjeren na suzbijanje nepismenosti među radnicima u gradovima i radničkom omladinom, a na radnike u agraru nije se računalo u tom prvom valu opismenjavanja. Borba protiv nepismenosti postala je glavna parola kulturnoga rada u zimi 1945./1946. godine. „Još ove zime treba likvidirati nepismenost u svakoj radionici, tvornici, poduzeću i ustanovi." ${ }^{25}$ Najveća aktivnost u opismenjavanju očekivala se od sindikalnih povjerenstava, koja su i obavljala najintenzivniju propagandu protiv nepismenosti predavanjima o koristi i vrijednosti znanosti, o potrebi za usavršavanjem na stručnom planu, o važnosti umjetnosti. Često geslo poticaja nalazilo se ispisano na panoima tvorničkih odjeljenja: „Druže, ne smije biti niti jednog nepismenog radnika ili radnice u tvom poduzeću koji ne bi za ovih zimskih mjeseci naučio čitati, pisati i računati. ${ }^{26}$ Opismenjavanje nije bilo usmjereno, bar prema planovima, samo na učenje potpisa, nego je shvaćano kao temelj za daljnju društvenu izgradnju. Upravo se zato pismenost smatrala „oružjem” pomoću kojega će se usvojiti znanje da bi se sasvim ovladalo strojem, poduzećem, a na kraju čitavim gospodarstvom. Uklanjanjem nepismenosti stvaralo se „preduslove za naše konačne pobjede na svim poljima naše djelatnosti" ${ }^{27}$ Bez pismenih radnica i radnika nije se mogao graditi socijalizam jer su oni u najvećoj mogućoj mjeri mogli biti iznimno korisni u obnovi i razvoju privrede s ciljem poboljšanja njihova životnoga standarda. Angažman Glavnoga odbora Jedinstvenih sindikata radnika i namještenika Jugoslavije u suzbijanju nepismenosti bio je izvanredno važan jer je upravo na njegovu 4. plenumu opismenjavanje istaknuto kao jedan od najvažnijih

\footnotetext{
SPEHNJAK, Javnost i propaganda, 208.

„Nepismenost je - neprijatelj naroda”, Glas rada, 11. 1. 1946., 6.

Isto.

Isto, 4
} 
problema u „kulturno-masovnom radu”, a smatrano je nužnim preduvjetom „sistematskom ideološkom uzdizanju” ${ }^{28}$ Natjecanje kao općerašireno sredstvo za pomoć u izgradnji koristilo se, dakako, i na ovom polju. Ideja je bila početi s natjecanjem među tečajevima, a u njima su se natjecali polaznici u svojem napredovanju na radu te voditelji prema uspjehu polaznika. Polaznike, voditelje, organizatore i propagatore tečajeva za nepismene planiralo se s obzirom na postignute rezultate proglašavati udarnicima. Sva su mjesna sindikalna vijeća i zemaljska tajništva svakih četrnaest dana trebala slati izvještaje Zemaljskom kulturno-prosvjetnom odboru Jedinstvenih sindikata radnika i namještenika Jugoslavije za Hrvatsku da bi se moglo nadzirati napredovanje i usmjeriti ili popraviti rad sindikalnih organizacija zaduženih za izvođenje tečajeva. ${ }^{29}$ Učiteljsko udruženje Hrvatske ušlo je u sastav Jedinstvenih sindikata radnika i namještenika Jugoslavije. U Savez prosvjetnih radnika i namještenika Jugoslavije bili su učlanjeni učitelji, profesori, nastavnici i tehničko osoblje. ${ }^{30}$

\section{Problemi i metode kampanje}

Tijekom 1947. brojna mjesna i kotarska sindikalna vijeća nisu imala evidenciju o broju nepismenih ni plan rada analfabetskih tečajeva, a manji je broj bio u procesu pripreme. Tako je primjerice na području Mjesnoga sindikalnog vijeća Karlovac bilo otvoreno pet tečajeva sa 37 polaznika, a 182 nepismena radnika ostala su neobuhvaćena. U Šibeniku je radilo pet tečajeva sa 105 polaznika, a 560 nepismenih ostalo je izvan programa; u Solinu su radila tri tečaja sa 21 polaznikom, a 229 nepismenih ostalo je neobuhvaćeno. U Osijeku je bilo formirano četrnaest tečajeva, ali se zbog nepostojanja evidencije nije moglo doći do broja polaznika i nepismenih. Ovi primjeri pokazuju goleme poteškoće u opismenjavanju. One su zasigurno bile posljedica nedovoljnoga angažmana sindikalnih čelnika u uvjeravanju i privlačenju velikoga broja nepismenih na tečajeve. Moć uvjeravanja sindikalnih aktivista bila je neobično važna za broj polaznika tečajeva. Pri animiranju novih polaznika najviše se pozornosti posvećivalo objašnjenju da je opismenjavanje važno za njihovo daljnje uzdizanje jer je upravo o njemu ovisila izgradnja društveno-političkoga poretka, a ona je trebala dovesti do poboljšanja kvalitete života svakoga pojedinca. $U$ borbi za iskorjenjivanje nepismenosti ponajviše problema imali su strukovni savezi rudara, šumskih, poljoprivrednih i građevinskih radnika. Te grupe radnika nakon radnoga vremena odlazile su svojim kućama. Kako im je mjesto 
stanovanja bilo udaljeno od radnoga mjesta, nisu nalazili shodnim biti ondje izvan radnoga vremena. ${ }^{31}$

Za suzbijanje nepismenosti preporučivale su se metode sovjetske znanstvenice Nadežde Konstantinove Krupske. U članku „Kako treba čitati novine” Krupska kaže sljedeće: „Mnogi znadu čitati novine, ali čitaju suviše sporo. Sva njihova pažnja odlazi na to, da shvate pojedine riječi. Radi toga teško im je da prate smisao štiva. Treba se naučiti čitati brzo. Treba izabrati u novini kakav kraći zanimljiv članak, pročitati ga jedanput, drugi i treći put, pročitati ga na glas, a zatim u sebi. Treba postići to da čitanje ide sasvim glatko. Drugoga dana treba pročitati ponovo taj isti članak. Treba čitati neizostavno svaki dan, makar i malo. Tada će, kroz nekoliko sedmica, kroz mjesec dana, biti postignuti veliki uspjesi." ${ }^{2}$

Želja je bila novoopismenjene što prije pridobiti za čitanje novina da bi se mogli što prije koristiti „tim našim najjačim oružjem za širenje tekovina socijalističke kulture u narodne mase". ${ }^{33}$ Od svih aktivista koji su sudjelovali kao poučavatelji u analfabetskim tečajevima tražilo se da nađu pogodne metode za praktičnu pomoć svim novoopismenjenima u njihovu daljnjem razvoju, a metode Krupske smatrane su iznimno korisnima. Opismenjavanje nije bilo važno samo za društveno-gospodarski napredak, nego upravo za propagandu i širenje ideja.

\section{Analfabetski tečajevi}

Svi spomenuti pokušaji, koliko god u organizacijskom smislu naoko izgledali solidno strukturirani, bili su sporadični i loše provedeni. Upravo zato analfabetski tečajevi nisu imali većega uspjeha. Kao što je napomenuto u uvodu, ozbiljniji pristup opismenjavanju započeo je 1947., no sama akcija već u početku je imala čitav niz propusta. Iz prvih objavljenih podataka mjesnih sindikalnih vijeća o opismenjavanju razabiru se ozbiljni propusti u funkcioniranju tečajeva za nepismene.

\footnotetext{
${ }^{31}$ „Za potpunu likvidaciju nepismenih”, Glas rada, 24. 10. 1947., 9.

Isto.

Isto.
} 
Tablica 1. Analfabetski tečajevi u organizaciji mjesnih sindikalnih vijeća

\begin{tabular}{|l|r|r|}
\hline \multicolumn{1}{|c|}{ Mjesno sindikalno vijeće } & Nepismenih & $\begin{array}{c}\text { Broj nepismenih na } \\
\text { tečajevima }\end{array}$ \\
\hline Daruvar & 833 & 88 \\
\hline Dubrovnik & 161 & 97 \\
\hline Karlovac & 178 & 53 \\
\hline Nova Gradiška & 41 & 20 \\
\hline Slavonski Brod & 301 & 33 \\
\hline Split & 192 & 80 \\
\hline Šibenik & 470 & 120 \\
\hline Zadar & 39 & 11 \\
\hline Zagreb & 923 & 553 \\
\hline Zlatar & 135 & 31 \\
\hline
\end{tabular}

Izvor: „Uklanjajmo nedostatke i slabosti u borbi za opismenjavanje našeg članstva”, Glas rada (Zagreb), 12. 12. 1947., 7.

Iz navedenih podataka vidljiva je organizacijska slabost sindikalnih vijeća u provedbi analfabetskih tečajeva. Zasigurno je najočitiji primjer loše organiziranosti bilo Mjesno sindikalno vijeće Zagreb, gdje je bilo relativno malo nepismenih, a mogućnosti za potpunu eliminaciju nepismenosti mnogo povoljnije u odnosu na sva druga mjesta s obzirom na broj potencijalnih poučavatelja. Prema tome, Zagreb je trebao prednjačiti u akciji opismenjavanja među svojim članstvom. Prema podacima Ministarstva prosvjete Narodne Republike Hrvatske objavljenim u Glasu rada, opća kampanja iz 1947. uspjela je broj nepismenih smanjiti za $23 \%$ (tijekom kampanje do 30. lipnja čitati i pisati naučilo je oko 46000 osoba). Kampanja opismenjavanja u propagandnom je smislu bila organizirana veoma kvalitetno, no najveći problem bio je u provedbi. Dobar dio sindikalnih organizacija od svojih predstavnika u centru za suzbijanje nepismenosti nije dobivao smjernice koje je centar upućivao pojedinim organizacijama i područjima. Priličan je problem bila činjenica da je akcija vođena okružnicama. Najmanje pozornosti posvećivalo se grupama gdje je bilo najviše nepismenih radnika, a to je bilo na poljoprivrednim dobrima, građevinskim radovima, šumskim sječama, u rudnicima i ciglanama, odnosno na radilištima sezonskih radnika. Ostali dio nepismenih u proizvodnji bile su žene zaposlene u tekstilnoj industriji, na poljoprivrednim dobrima, $\mathrm{u}$ tvornicama duhana i među kućnim pomoćnicama. ${ }^{34}$

Usprkos svim poteškoćama, od 1946. do 1952. na tečajevima je, na državnoj razini, opismenjeno oko 70000 mladih ljudi. ${ }^{35}$

\footnotetext{
34 „Treba odlučno nastaviti borbu protiv nepismenosti radnika”, Glas rada, 14. 11. 1946., 4.

35 SELINIĆ, „Počeci socijalističkog Novog Beograda”, 89.
} 


\section{Djelovanje sindikalnih podružnica}

Rad na prevenciji nepismenosti nastavljen je i u idućim godinama. Smatralo se da su sindikalne podružnice postigle zapažene rezultate u opismenjavanju, ponajprije da bi što više radnika dobilo mogućnost daljnjega političkog i stručnog obrazovanja. Usprkos takvim rezultatima, zbog gotovo svakodnevnoga priljeva seoskoga stanovništva u gradove i uključivanja u privredu broj nepismenih radnika 1949. se povećavao. Glavni odbor Jedinstvenih sindikata radnika i namještenika Jugoslavije poslužio se pozivom na natjecanje u suzbijanju nepismenosti uz pomoć svojih mjesnih i kotarskih vijeća, mjesnih odbora, sindikalnih podružnica i svih članova kao jednom od metoda za iskorjenjivanje toga problema. Tijekom samoga natjecanja željelo se broj od otprilike 5000 nepismenih radnika što je moguće više smanjiti. Ideja je bila organizirati natjecanje što masovnije da bi se maksimizirao broj obuhvaćenih tečajevima. Zbog prijašnjih iskustava željelo se da upisani polaznici doista završe tečaj. Pismena i usmena propaganda u tom su smislu igrale važnu ulogu. U odnosu na poratne godine, četiri godine poslije natjecanje se u organizacijsko-provedbenom smislu, što se tiče poučavatelja, ali i polaznika, nije temeljilo isključivo na rodoljubnoj osnovi. Tako 1949. u natjecanju za suzbijanje nepismenosti postoji sustav nagrada. ${ }^{36}$ Kotarska sindikalna vijeća nagrađivala su poučavatelje prema postignutim rezultatima: prva nagrada bio je radijski prijamnik i biblioteka u vrijednosti od 5.000 dinara, a nagrade od drugoga do petoga mjesta bile su biblioteke u vrijednosti od 700 do 3.000 dinara. ${ }^{37}$

U većim su poduzećima sindikalne podružnice u pravilu bile dobro organizirane, kao što je to bio slučaj sa sindikalnom podružnicom poduzeća Varteks u Varaždinu, gdje su formirane čitateljske grupe označene kao baze za uzdizanje radnika na prosvjetnom polju. Tvornica Varteks uspjela je na doškolovanje pridobiti $80 \%$ svojih radnika. ${ }^{38}$

Nisu sva velika poduzeća poput Varteksa bila uspješna u opismenjavanju svojih radnika, o čemu svjedoče i izvještaji iz šećerane u Županji i riječkoga brodogradilišta: „Masovne organizacije ne pružaju dovoljno pomoći u radu i ne preuzimaju obaveze. Još uvijek podbacuje naročito rad sindikata na likvidaciji nepismenosti. Radnici šećerane u Županji i brodogradilišni radnici u Rijeci traže na masovnom sastanku da im se pohađanje analfabetskih tečaja plati kao prekovremeni rad." 39

36 „Poziv na takmičenje u suzbijanju nepismenosti”, Glas rada, 13. 1. 1949., 3.

37 Isto

38 HR-HDA-1286-SSJ VSSH, kut. 236, „Izvještaj sindikalne podružnice br. 1 Varteks Varaždin, upućene Savezu radnika i namještenika industrije tekstila i odjeće Jugoslavije”, broj 1862/47., 4. 4. 1947., 3.

39 SPEHNJAK, Javnost i propaganda, 213. 
Druga faza: sustavne mjere šezdesetih godina

\section{Pojačana briga za odgojno-obrazovna pitanja}

Početkom šezdesetih godina mijenja se strategija u borbi protiv elementarne nepismenosti. U prethodnom se razdoblju uz pomoć brzih tečajeva sanirala gruba slika velikoga broja nepismenih, ali i dalje je ostao problem nedovoljne pismenosti i obrazovanosti, pa se u drugoj fazi stavlja veći naglasak na pojačanu brigu za rješavanje toga problema. Imperativ Saveza komunista Jugoslavije (SKJ) jest izgradnja socijalističkih društvenih odnosa i preko odgojno-obrazovnoga sustava. Obrazovne promjene započele su sredinom pedesetih godina. Uvođenjem obvezne osmogodišnje škole smanjuje se nepismenost u mlađoj populaciji. ${ }^{40} \mathrm{Za}$ razliku od prijašnjega razdoblja, šezdesetih i sedamdesetih godina sustavna borba protiv nepismenosti i polupismenosti vodi se stjecanjem tzv. funkcionalne pismenosti da bi se polaznike osposobilo u osnovama pisanja i čitanja. ${ }^{41}$ Opismenjavanje se provodi najčešće u sklopu osnovnih škola, a za radno aktivno stanovništvo pod vidom osnovnoga obrazovanja odraslih. Formirane su škole za kvalificirane radnike, škole za ostali stručni kadar, tehničke i druge stručne škole, škole za visokokvalificirane radnike i druge. ${ }^{42} \mathrm{Te}$ škole rade po posebnim programima namijenjenim odraslima i redovito u večernje sate. Osim u sklopu osnovnih škola, u privrednim organizacijama i tvorničkim poduzećima formirali su se školsko-tvornički centri koji su organizirano obrazovali radnike uz rad. Obrazovanje je provođeno od elementarne pismenosti do viših oblika stjecanja stručne spreme. ${ }^{43}$

Pojačana briga vladajuće elite za odgojno-obrazovna pitanja uvelike je utjecala na promjene obrazovnoga sustava. Škola se proglašava samoupravnom radnom organizacijom od posebne društvene važnosti. Odgojno-obrazovni ciljevi zasnovani su na učenju klasika marksizma, gdje se kao uporište postavlja marksistička koncepcija odgoja i obrazovanja..$^{44} \mathrm{Da}$ bi se promjene sustavno provodile te kontrolirao rad škola i nastavnika, ali radi unaprjeđiva-

\footnotetext{
40 POTKONJAK, Sistem obrazovanja i vaspitanja u Jugoslaviji, 87. Cilj je bio ozakonjenje osmogodišnjega osnovnog obrazovanja, ali i sustavna izgradnja socijalističkih društvenih odnosa.

${ }_{41}$ HR-HDA-1416-ZPPS SRH, kut. 20, spis br. 107/2-1974. O funkcionalnoj pismenosti i značenju pojma može se pronaći informacija u spisima o obrazloženju osnutka Komisije za borbu protiv nepismenosti.

${ }_{42}$ OGRIZOVIĆ, „Školstvo i prosvjeta u socijalističkoj Jugoslaviji”, 31.

43 Isto, 31-32.

${ }_{44}$ Značenje Marxa i Engelsa osobito je bilo važno za socijalističku pedagogiju; na tim temeljima postavljeno je uporište za razvoj marksističke koncepcije odgoja i obrazovanja. Iako oni nisu pisali posebne pedagoške rasprave, dali su temeljne postavke za odgojne ideale iz kojih proizlaze odgojno-obrazovni ciljevi. Socijalističko učenje i marksistička koncepcija odgoja i obrazovanja naglašavaju da je cilj odgoja razvoj čovjeka umnim i fizičkim odgojem s potrebom spajanja proizvodnoga rada i nastave. Vidi: ZANINOVIĆ, Opća povijest pedagogije, 198.
} 
nja njihova rada, 1958./1959. osnovan je Prosvjetno-pedagoški zavod (Zavod za školstvo). ${ }^{45}$ Jedan u nizu konstantnih problema odnosio se na nedostatak obrazovanoga nastavničkoga kadra na svim razinama. Manjkavost obrazovanja nastavnika bila je posljedica nedovoljnoga pedagoškog, psihološkog i andragoškog pristupa. Primjerice, nastavnici stručnih predmeta u stručnim školama nemaju za vrijeme studija gotovo nikakve mogućnosti za pedagoško i metodičko obrazovanje. ${ }^{46}$ Znatan dio nastave u osnovnim i srednjim školama izvodi se nestručno ili uz pomoć honoriranih nastavnika. ${ }^{47}$

Uz problem nepismenosti, u Socijalističkoj Republici (SR) Hrvatskoj bio je vrlo nizak stupanj odgovarajuće obrazovanosti. Na taj se način razlikovala nepismenost od polupismenosti. U toj fazi polupismenost je značila nedovoljan stupanj obrazovanosti, a odnosila se na one koji imaju završen jedan do tri razreda osnovne škole, što im nije bilo dostatno u obavljanju određenih poslova. Primjerice, sve do početka šezdesetih godina u narodnim odborima čak 70 \% službenika nije imalo odgovarajuću stručnu spremu. ${ }^{48} \mathrm{Zbog}$ toga, prema tadašnjem stavu SKJ, stanje u obrazovnom sustavu nije bilo zadovoljavajuće. Oštro se kritiziralo dotadašnje tzv. dualističko obrazovanje, koje se definiralo postojanjem strukovnih škola i gimnazija. ${ }^{49}$ Kritike su se odnosile na sve razine obrazovanja, na nedovoljnu usklađenost s potrebama privrednih i društvenih djelatnosti. Osim toga kritiziralo se neplansko izgrađivanje školske mreže i nedovoljnu vertikalnu i horizontalnu povezanost pojedinih stupnjeva obrazovanja. Može se istaknuti da je u tom razdoblju obrazovanje odraslih napredovalo, ali još uvijek nije dovoljno uključeno u cjelokupni odgojno-obrazovni sustav. Obrazovanje uz rad nije našlo svoje mjesto u normativnoj djelatnosti radnih organizacija iako su i dotadašnja iskustva pokazivala široke mogućnosti njegova korištenja. To će biti jedan od prioriteta idućih reformskih promjena, izražen potrebom spajanja proizvodnoga rada i nastave. U idućim razdobljima obrazovanje odraslih sve će se više profilirati kao ključ rješavanja problema nepismenosti i nedovoljne obrazovanosti.

\section{Zakonska uporišta za promjene}

U lipnju 1961. osnovani su odvojeni republički savjeti. ${ }^{50}$ Proces sustavnih promjena u obrazovanju zasnovan je na Ustavu Socijalističke Federativne Re-

45 Danas Agencija za odgoj i obrazovanje (AZOO).

46 OGRIZOVIĆ, „Školstvo i prosvjeta u socijalističkoj Jugoslaviji”, 197.

47 Isto.

48 RADELIĆ, Hrvatska u Jugoslaviji, 322.

49 ŠUVAR, Škola i tvornica, 30.

50 HEĐBELI, MOKROVIĆ, „Pregled uprave u Hrvatskoj”, 212. Godine 1953. postojali su savjeti koji su obavljali poslove društvenoga upravljanja od općega interesa u području prosvjete, 
publike Jugoslavije iz 1963., a trajao je više godina, sve do 1974., kada je Savezna skupština donijela Rezoluciju o razvijanju odgoja i obrazovanja na samoupravnoj osnovi. ${ }^{51}$ Ustav nalaže novi koncept društvenih odnosa, koji ističe rad i radnoga čovjeka kao nositelja socijalističkoga preobražaja društva. ${ }^{52}$ Zahtjevi za promjene formulirani su i u nekoliko važnih dokumenata: zaključcima 8. kongresa SKJ 1964., Zakonu o ustanovama, odlukama Savezne skupštine o privrednoj i društvenoj reformi i Općem zakonu o financijskim sredstvima za obrazovanje i odgoj. ${ }^{53} \mathrm{U}$ inicijativi odgojno-obrazovne preobrazbe, osim Savjeta za prosvjetu, sudjeluju i društveno-političke organizacije, sindikat, Vijeće kulturno-prosvjetnih saveza, republički savezi radničkih i narodnih sveučilišta i sl. Godine 1962. Narodno sveučilište preimenovano je u Radničko sveučilište „Moša Pijade”. ${ }^{54} \mathrm{Uz}$ ostalu izdavačku djelatnost pokreće se i časopis Radnik i obrazovanje, koji informira i potiče radništvo na obrazovanje. ${ }^{55}$ U sklopu Radničkoga sveučilišta organizirana je osnovna škola za odrasle, srednja radnička škola (svojevrsna radnička gimnazija), viša kadrovska škola koja je obrazovala kadrovske stručnjake u tvornicama, viša tehnička škola za sigurnost na radu (iz koje je izrasla današnja Visoka škola za sigurnost) te tzv. granski centri, koji su osposobljavali zaposlene za pojedina radnička zanimanja. ${ }^{56}$ Zadatak je Radničkoga sveučilišta „Moša Pijade” pomagati radnim organizacijama iz privrede u osposobljavanju radnika. Radnici se osposobljavaju za određena zanimanja prema „društveno priznatim” programima kojima se stječe stupanj stručnoga obrazovanja kvalificiranoga (KV) i visokokvalificiranoga (VKV) radnika. ${ }^{57}$ Šezdesetih i sedamdesetih godina velike privredne organizacije, Prvomajska, Tvornica papira, Hidroelektra, „Vladimir Gortan”, Gradska kanalizacija u Zagrebu i dr., šalju svoje radnike na osposobljavanje. ${ }^{58}$

znanosti i kulture, narodnoga zdravlja i socijalne zaštite te se za obavljanje upravnih poslova iz nadležnosti republičkih organa u tim područjima osnivaju savjeti. Tada su se nazivali: Savjet za prosvjetu, nauku i kulturu, Savjet za narodno zdravlje i socijalnu politiku. Od 24. lipnja 1961. osnovani su posebni republički savjeti: Savjet za prosvjetu, Savjet za kulturu, Savjet za naučni rad, Savjet za narodno zdravlje, Savjet za socijalnu zaštitu. Savjet za prosvjetu ima zadatak riješiti odgojno-obrazovne probleme te razvijati sve razine sustava s ciljem sustavne izgradnje socijalističkih društvenih odnosa.

51 PODREBAC, Socijalistički samoupravni preobražaj odgoja i obrazovanja u SR Hrvatskoj, 363.

52 Ustav SFRJ (1963), 31-39.

53 OGRIZOVIĆ, „Školstvo i prosvjeta u socijalističkoj Jugoslaviji”, 197-198.

54 OBAD, „Nakladništvo kao dio obrazovanja odraslih”, 1-3. Radničko sveučilište danas je Pučko otvoreno učilište. Nekoć je nazivano rasadnikom prosvjetnoga rada i obrazovanja odraslih.

55 Radnik i obrazovanje (Zagreb), 1961., br. 2, 116. Zanimljivo je da se takav oblik obrazovanja naglašava (u izvorima) kao samoobrazovanje.

56 PASTUOVIĆ, „Uloga Pučkog otvorenog učilišta Zagreb”, 10.

57 VELČIĆ, MARKOVIĆ, VELČIĆ, Radničko sveučilište u obrazovanju kadrova iz privrede, 84.

$58 \quad$ Isto, 77. 
Analize i novi koncepti

Komisija za borbu protiv nepismenosti izradila je analizu stanja nepismenosti na temelju podataka iz popisa stanovništva 1961. u odnosu na popis stanovništva 1971. godine. Analiza je služila Komisiji u poduzimanju mjera koje su trebale iskorijeniti nepismenost.

$\mathrm{U}$ tablici 2 vidljivo je kretanje stope nepismenosti u četiri dobne grupe. Analiza pokazuje podijeljenost SR Hrvatske na četiri makroregije i šest regija. Može se pratiti koja dobna skupina u kojoj regiji spada u kritičnu skupinu po broju nepismenih. Zabrinjavajući je udio nepismenih u ličkoj regiji (18,57 \%) i dalmatinskoj makroregiji (13,99 \%). Od 1961. do 1971. vidljiv je i ukupan broj nepismenih na razini SR Hrvatske - 8,95\%. Najveći udio nepismenih u SR Hrvatskoj $(29,26 \%)$ čine oni u dobi od 65 i više godina, a najmanje je onih u dobi od 10 do 19 godina (samo 1,33 \%). Dobar rezultat među mlađom populacijom povezan je sa zakonskom obvezom pohađanja osnovne škole. Međutim, stanje i dalje nije povoljno jer smanjenje ovisi o najstarijoj dobnoj skupini, koju najviše pogađa smrtnost. Evidentno je da je nepismenost i dalje prisutna i u populaciji srednje životne dobi, koja je radno aktivna, što je otvorilo prostor za osmišljavanje novoga koncepta radi potpune likvidacije nepismenosti. Podaci upućuju na potrebu obrazovanja odraslih, što je preraslo u permanentan zadatak društvene zajednice povezan s potrebom tehnološkoga i tehničkoga razvitka privrede. Iz dokumenata je vidljivo tumačenje da su se aktivnosti konstantnoga obrazovanja intenzivirale afirmacijom radničkoga i društvenoga samoupravljanja, čiji proces zahtijeva da proizvođač i upravljač budu aktivni i samoinicijativni. Analize tih podataka dovele su Komisiju za borbu protiv nepismenosti do zaključka da treba stvoriti novi koncept borbe protiv nepismenosti.

Treća faza: najava obrazovnih promjena sedamdesetih godina

Razdoblje između dva popisa stanovništva od 1961. do 1971. pokazuje da je nepismenost u SR Hrvatskoj i dalje relativno visoka. Nepismenost će u tih deset godina blago pasti sa $12,9 \%$ na $8,95 \%$. To je jedan od razloga zašto će se sedamdesetih godina primjenjivati novi koncept sustavnih mjera da bi se smanjila stopa nepismenosti, ponajviše među radno aktivnim dijelom stanovništva. Činjenice pokazuju da je nepismenost ili polupismenost radno aktivnoga stanovništva još uvijek društveno-gospodarska prepreka u ostvarenju zamišljenoga koncepta, prema kojem „nepismen čovjek ne može unaprjeđivati proizvodnju i samoupravljanje. On kao takav ne može ni stručno napredovati. $\mathrm{Na}$ njega se isključivo gleda kao na radnu snagu. Opismenjavanje bi moralo, barem za aktivno stanovništvo postati zakonska obaveza". ${ }^{59}$

59 HR-HDA-1416-ZPPS SRH kut. 20, „Informacija o stanju nepismenosti”, 3. 


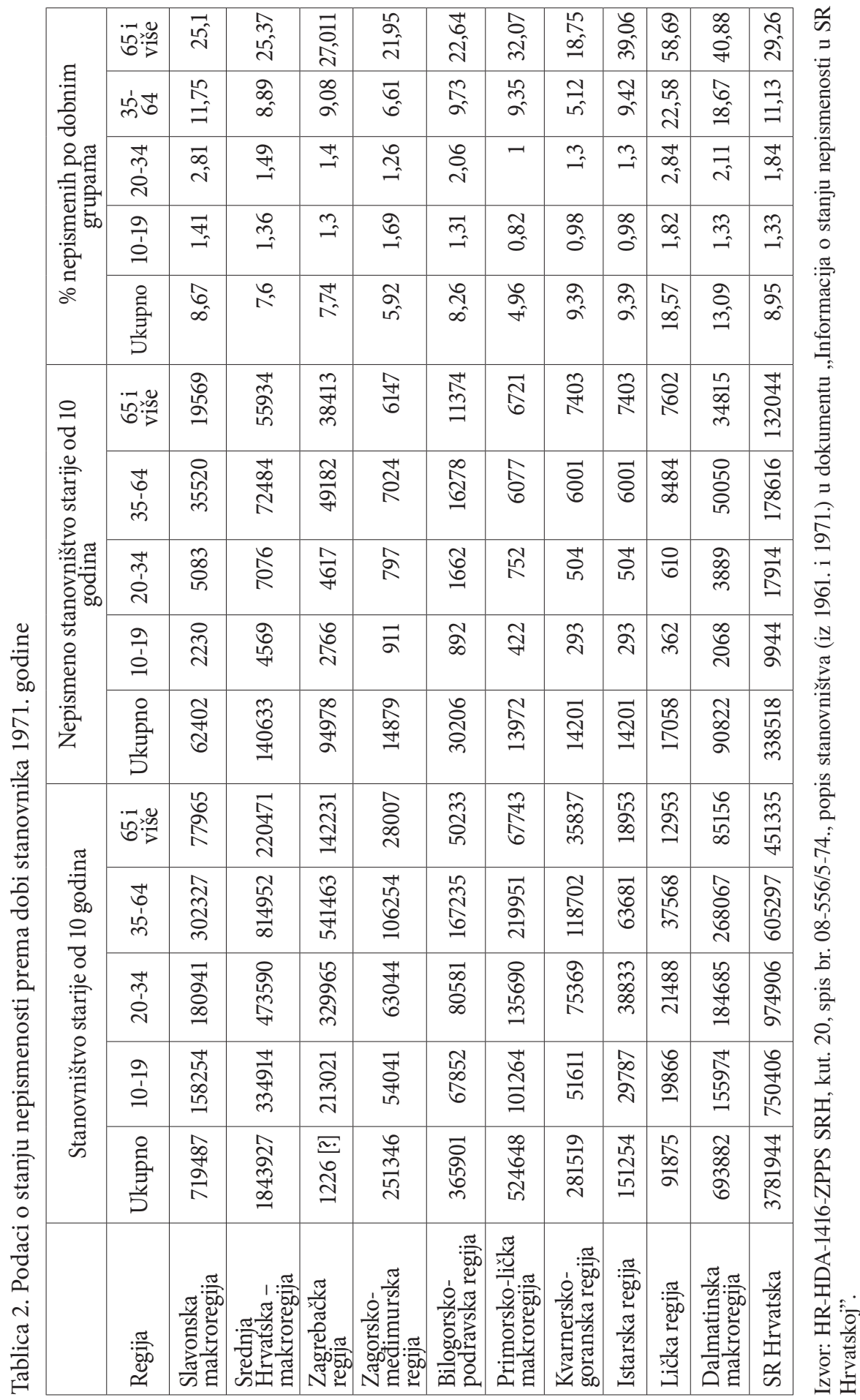


Tablica 3. Nepismenost po općinama s preko $20 \%$ nepismenih

\begin{tabular}{|c|c|c|c|c|c|c|c|}
\hline \multirow[b]{2}{*}{ Općina } & \multirow{2}{*}{$\begin{array}{c}\text { Nepismenih } \\
\text { 1961.(\%) }\end{array}$} & \multirow{2}{*}{$\begin{array}{c}\text { Ukupan broj } \\
\text { stanovnika } \\
1971 .\end{array}$} & \multirow{2}{*}{$\begin{array}{c}\text { Nepismenih } \\
\text { 1971.(\%) }\end{array}$} & \multicolumn{4}{|c|}{ Od toga prema dobi ( \%) } \\
\hline & & & & $10-19$ & $20-34$ & $35-64$ & 65 i više \\
\hline Benkovac & 30,8 & 28.862 & 23,67 & 2,01 & 6,58 & 44,42 & 58,25 \\
\hline Donji Lapac & 31,4 & 8.184 & 26,17 & 1,01 & 3,56 & 39,89 & 68,89 \\
\hline Drniš & 32 & 30.132 & 26,05 & 1,64 & 3,28 & 42,55 & 69,99 \\
\hline Dvor & 30,3 & 15.878 & 23,54 & 0,98 & 5,16 & 35,33 & 62,41 \\
\hline Glina & 28,2 & 24.643 & 21,43 & 1,17 & 3,73 & 29,16 & 55,47 \\
\hline Gračac & 30,3 & 12.806 & 25,51 & 1,51 & 4,27 & 34,45 & 67,18 \\
\hline Knin & 26,1 & 38.917 & 20,88 & 0,86 & 3,27 & 32,55 & 63,57 \\
\hline Obrovac & 41,9 & 10.343 & 32,92 & 8,56 & 15,02 & 57,21 & 78,03 \\
\hline Sinj & 26,2 & 45.119 & 20,69 & 1,2 & 3,48 & 33,98 & 57,56 \\
\hline Slunj & 32,9 & 21.129 & 25,43 & 2,51 & 7,81 & 41,01 & 64,03 \\
\hline Trogir & 27,7 & 15.717 & 23,05 & 1,23 & 2,42 & 33,2 & 64,95 \\
\hline Vojnić & 27 & 8.497 & 25,19 & 3,83 & 6,45 & 36,13 & 58,55 \\
\hline Vrginmost & 26,7 & 19.101 & 21,53 & 1,45 & 3,35 & 29,77 & 64,84 \\
\hline
\end{tabular}

Izvor: HR-HDA-1416-ZPPS SRH, kut. 20, spis br. 08-556/5-74., popis stanovništva (iz 1961. i 1971.) u dokumentu „Informacija o stanju nepismenosti u SR Hrvatskoj”.

Posebno je zabrinjavajuće za komunističke vlastodršce bilo to što je u nekim općinama veliki udio nepismenih bio u dobnim skupinama mlađih stanovnika, od 20 do 34 godine, kao i onih od 35 do 64 godine, što je vidljivo iz tablice 3. Po broju nepismenih u najkritičnijoj skupini radno aktivnoga stanovništva prednjače općine Obrovac i Slunj, a zatim Benkovac i Vojnić. To alarmantno stanje zahtijevalo je znatno veći angažman šire društveno-političke zajednice. Zato će se krenuti u treću fazu likvidacije nepismenosti i polupismenosti.

Tablica 4. Stanovništvo prema dobi, pismenosti i aktivnosti 1971. godine

\begin{tabular}{|l|r|r|r|r|r|r|}
\hline & \multicolumn{1}{|c|}{ Ukupno stanovništvo starije od 10 godina } & \multicolumn{3}{|c|}{ Aktivno stanovništvo } \\
\hline $\begin{array}{c}\text { Dobne } \\
\text { skupine }\end{array}$ & Svega & $\begin{array}{c}\text { Od toga } \\
\text { nepismenih }\end{array}$ & $\begin{array}{c}\text { \% } \\
\text { nepismenih }\end{array}$ & \multicolumn{1}{c|}{ Svega } & Nepismenih & $\begin{array}{c}\% \\
\text { nepismenih }\end{array}$ \\
\hline Ukupno & 3.781 .944 & 3.381 .518 & 8,95 & 2.015 .918 & 116.523 & 5,53 \\
\hline $10-14$ & 358.212 & 6.324 & 1,77 & 6.290 & 203 & 3,22 \\
\hline $15-19$ & 392.194 & 3.620 & 0,92 & 144.756 & 1.071 & 0,74 \\
\hline $20-24$ & 367.463 & 3.714 & 1,01 & 267.708 & 1.369 & 0,51 \\
\hline $25-29$ & 276.268 & 4.864 & 1,76 & 224.384 & 2.240 & 1,00 \\
\hline $30-34$ & 331.175 & 9.336 & 2,82 & 262,408 & 4.576 & 1,74 \\
\hline $35-39$ & 354.804 & 17.382 & 4,88 & 274.536 & 9.363 & 3,41 \\
\hline $40-44$ & 336.731 & 20.551 & 6,10 & 244.578 & 10.366 & 4,24 \\
\hline $45-49$ & 284.760 & 22.966 & 8,07 & 177.650 & 10.251 & 5,77 \\
\hline $50-54$ & 178.496 & 19.238 & 10,78 & 101.876 & 8.145 & 8,01 \\
\hline $55-59$ & 219.246 & 40.339 & 18,40 & 101.876 & 15.735 & 15,44 \\
\hline $60-64$ & 231.260 & 58.194 & 25,16 & 88.417 & 21.568 & 24,39 \\
\hline 65 i više & 427.058 & 119.585 & 28,00 & 115.522 & 29.232 & 25,30 \\
\hline Nepoznato & 24.277 & 12.459 & 51,32 & 6.095 & 2.406 & 39,47 \\
\hline
\end{tabular}

Izvor: HR-HDA-1416-ZPPS SRH, kut. 20, spis br. 08-556/5-74., popis stanovništva (31. ožujka 1971.) u dokumentu „Informacija o stanju nepismenosti u SR Hrvatskoj”. 
Podaci u tablici 4 odnose se na kriterij praćenja stanovništva prema dobnim skupinama, pismenosti i aktivnosti. Može se primijetiti da se podaci prikupljaju od desete godine života. Naime, osnovno obrazovanje počinje od sedme godine, pa se ipak očekivalo da će do desete godine biti pismeni. No radi potrebe istraživanja analiza je usredotočena na radno aktivno stanovništvo, zbog kojega je i započela treća faza. Dakle, podaci su potvrdili da postoji veliki problem nepismenosti radno aktivnoga stanovništva. Zabrinjavajući rast stope nepismenosti vidljiv je u populaciji u dobi od 35 do 64 godine, stoga će se $\mathrm{u}$ idućih deset godina ponajviše sustavno raditi na obrazovanju odraslih osnivanjem posebnih škola za njihovo osnovno obrazovanje.

\section{Poduzete mjere i praktični dio}

Novim Ustavom i smjernicama iz zaključka 10. kongresa SKJ 1974. federalnim jedinicama dana je određena sloboda da samostalno odlučuju o uvjetima i mogućnostima primjene obrazovne reforme u svojim odgojno-obrazovnim sustavima.$^{60}$ Glavni pokretač promjena odgojno-obrazovnoga sustava bio je ideološki, odnosno radilo se na redefiniranju odgojno-obrazovnoga sustava, koji bi bio potpuno prožet idejama marksizma i socijalističkoga samoupravljanja, u kojem je dotadašnji sustav postao neprihvatljiv. Budući da je samoupravljanje bilo jedna od prepoznatljivijih posebnosti jugoslavenskoga socijalizma, isti koncept preslikavao se i na promjene u odgojno-obrazovnom sustavu koje su zacrtane kao imperativ SKJ na 10. kongresu: „da kroz stalnu akciju osposobljava idejno-politički i organizacijski radi kako bi se aktivirale tzv. progresivne snage u rješavanju pitanja koja će postavljati dalji razvoj samoupravnog socijalističkog društva." ${ }^{11}$ Ti zaključci pokazuju da obrazovna reforma postaje jedno od ključnih političkih, ali i društvenih pitanja sedamdesetih godina. Oblikovani su novi metodološki i pedagoški standardi usmjereni na izgrađivanje marksističkoga pogleda na svijet u smislu prenošenja i usvajanja znanja, vještina i vrijednosti. Odgojno-obrazovni ciljevi temeljili su se na razvijanju intelektualno-spoznajnih svojstava i osobina ličnosti, formiranju potrebnih navika, izgradnji radne kulture i osposobljavanju svakoga za samoobrazovanje. ${ }^{62}$ Pedagoški standardi usmjereni su na oblikovanje tada novoga obrazovnog i intelektualnog profila svih sudionika u odgojno-obrazovnom sustavu,

\footnotetext{
60 Ustav SFRJ (1974) iscrpnije je i jasnije definirao samoupravne interesne zajednice kao relativno nov oblik samoupravnoga povezivanja. Ustanovljena je obveza konstituiranja mjesnih zajednica kao osnovnoga oblika samoupravnoga organiziranja radnih ljudi i građana na lokalnoj razini. U Ustavu je naglašena i razrađena društvena zaštita samoupravnih prava i društvenoga dobra te su utvrđeni organi koji ostvaruju tu zaštitu, unoseći u tu oblast i neke važne novine. Zaštićena su samoupravna prava radnih ljudi i društvenoga vlasništva.

${ }_{61}$ PODREBAC, Socijalistički samoupravni preobražaj odgoja i obrazovanja u SR Hrvatskoj, 374.

62 POTKONJAK, Sistem obrazovanja i vaspitanja u Jugoslaviji, 54.
} 
ali i rješavanje društveno-ekonomskih problema u državi. ${ }^{63}$ Polazeći od ciljeva i zadataka u Rezoluciji 10. kongresa, rješavanje nepismenosti još jednom je postalo jedan od neodgodivih društvenih i političkih zadataka. U ostvarivanju toga zadatka u zajedničkom nastojanju djelovale su osnovne organizacije udruženoga rada, mjesne zajednice, društveno-političke zajednice, interesne zajednice i odgojno-obrazovne institucije. Inicijativu je davao Prosvjetni savjet SR Hrvatske. ${ }^{64}$ Prosvjetni savjet raspravljao je o pojedinim pitanjima koja su poslije detaljnije rješavana na nadležnim sjednicama komisija.

\section{Osnutak Komisije za borbu protiv nepismenosti: akcijski planovi}

Na sjednici 29. svibnja 1974. Prosvjetni savjet ustanovio je da je problem nepismenosti u SR Hrvatskoj toliko važan da zahtijeva sveobuhvatnu društveno-političku i stručnu akciju za borbu protiv nepismenosti. ${ }^{65}$ Akciju je trebala pratiti Komisija za borbu protiv nepismenosti. Odluka o formiranju Komisije donijeta je na spomenutoj sjednici 1974 . godine. ${ }^{66}$ Komisija je radila na programu opismenjavanja i osnovnoga obrazovanja odraslih, uz poseban osvrt na polupismenost. Komisija je nosilac operativnih zadataka i akcija opismenjavanja. U odluci Prosvjetnoga savjeta istaknuto je da se „osnovni sadržaj ove akcije sastoji u funkcionalnom opismenjavanju omladine i radnoaktivnog stanovništva koje nije pismeno, ili se nije u stanju služiti pismom i knjigom". ${ }^{67}$

Prosvjetni savjet na svojoj je 20. sjednici u studenom 1974. donio Program za akciju opismenjavanja. Akcija je imala četiri faze: 1. potpuni obuhvat djece osnovnim obrazovanjem (do stjecanja preduvjeta za daljnje obrazovanje); 2. funkcionalno opismenjavanje aktivnoga stanovništva (predviđeno razdoblje od 1975. do 1978., a trebalo je obuhvatiti sve nepismene radnike i ostalo stanovništvo); ${ }^{68} 3$. osnovno obrazovanje mladih radnika (osnovno obrazovanje svih radnika do 40 godina starosti); 4 . stalno usavršavanje pismenosti (permanentno obrazovanje u smislu sprječavanja pojava polupismenosti među već opismenjenim stanovništvom) ${ }^{69}$ Koncept akcijskoga plana u završnoj fazi zamišljen je kroz tzv. funkcionalno opismenjavanje stanovništva, uklanjanje nepismenosti i polupismenosti, odnosno nedovoljne obrazovanosti. Smatralo

\footnotetext{
63 Isto, 54-55.

64 HR-HDA-1416-ZPPS SRH, kut. 20, spis br. 107/2-1974.

65 Isto.

66 Isto. Prosvjetni je savjet predsjednicom Komisije za borbu protiv nepismenosti imenovao Miru Krizmanić, članicu Prosvjetnoga savjeta Hrvatske. Uz nju je u Komisiji bilo još jedanaest članova.

67 HR-HDA-1416-ZPPS SRH, kut. 20, spis br. 2/5-392-1974.

68 Isto.

69 Isto. Faze su preuzete iz „Prijedloga mjera za akciju opismenjavanja”.
} 
se da je osoba funkcionalno pismena ako se može uključiti u sve aktivnosti u kojima je potrebna pismenost. Jedan od ključnih problema u toj trećoj fazi nepismenost je i polupismenost radno aktivnoga stanovništva, što je velika smetnja u ostvarivanju samoupravnoga socijalizma jer takav radnik ne pridonosi ostvarenju zadanih ciljeva.

Godine 1975. počela je akcija opismenjavanja i osnovnoga obrazovanja odraslih. Realizatori akcije su osnovne škole, škole za osnovno obrazovanje odraslih, organizacije udruženoga rada te narodna i radnička sveučilišta. ${ }^{70}$ Za pokretanje akcije i realizaciju zadataka na razini SR Hrvatske Prosvjetni savjet dodijelio je Komisiji za borbu protiv nepismenosti financijsku potporu u iznosu od 400.000 dinara. ${ }^{71}$ Ulaganje Prosvjetnoga savjeta u akciju opismenjavanja može se povezati s općenitim porastom financijskoga ulaganja u odgoj i obrazovanje sedamdesetih godina. U petogodišnjem razdoblju od 1975. do 1979. indeks uloženih sredstava u odgoj i osnovno obrazovanje raste (iznosio je $20,7 \%$ ), a u idućem petogodišnjem razdoblju smanjuje se na $14,5 \% .{ }^{72}$ Novčana sredstva Komisija je planirala namjenski utrošiti na izradu uputa i propagandnoga materijala, a za organizaciju akcije u općinama, mjesnim zajednicama i osnovnim organizacijama udruženog rada predviđeno je 100.000 dinara. Za izradu programa osposobljavanja nastavnika, metodičke upute, instrumentarij za praćenje akcija (izrada smjernica) predviđeno je 300.000 dinara. ${ }^{73}$ Prosvjetni savjet i Komisija akcije su provodili uz pomoć odgovarajućih stručnih institucija i suradnika, primjerice s Andragoškim centrom u Zagrebu. Centar je osnovan 1971. i bio je središte razvojnih i istraživačkih projekata na području obrazovanja odraslih. ${ }^{74}$ Organiziraju se konferencije i ljetne škole te razni tečajevi: za brzo čitanje, pisanje poslovnih i drugih pisama, sastavljanje diskusija i referata, pravljenje bilješki, korištenje pisanih informacija, praktična znanja i vještine iz matematike i tehničkoga crtanja i sl. ${ }^{75}$ Tako je Andragoški centar bio poznat po organizaciji Ljetne škole andragoga u Poreču i Zimske škole u Samoboru. U tu svrhu potiče se izrada metodičko-didaktičkih materijala, a sam Centar izdavao je od 1971. do 1990. časopis Andragogija. U suradnji s Andragoškim centrom nakladnička kuća Školska knjiga aktivno je djelovala u izdavanju potrebnih udžbenika i priručnika te objavila gotovo sve udžbenike

\footnotetext{
70 HR-HDA-1416-ZPPS SRH, kut. 20, spis br. 2/5-392-1974.

71 HR-HDA-1416-ZPPS SRH, kut. 20, spis br. 16/1-1975. Autori su za potrebe rada zatražili od Državnoga zavoda za statistiku podatak o prosječnoj mjesečnoj neto plaći za 1975., koja je iznosila 3.245 dinara. Ako se sredstva od 400.000 dinara koje je Prosvjetni savjet doznačio Komisiji za borbu protiv nepismenosti usporede s tadašnjom prosječnom plaćom u SR Hrvatskoj, zaključujemo da je iznos odgovarao iznosu od 123 prosječne mjesečne plaće.

72 PODREBAC, Socijalistički samoupravni preobražaj odgoja i obrazovanja u SR Hrvatskoj, 212.

73 HR-HDA-1416-ZPPS SRH, kut. 20, spis br. 01-193/75.

74 Isto.

75 HR-HDA-1416-ZPPS SRH, kut. 20, spis br. 253/1-1975. Uputa za rad radničkim sveučilištima.
} 
za osnovno obrazovanje odraslih. ${ }^{76}$ Može se reći da su šezdesete i sedamdesete godine XX. stoljeća doba vrhunca organiziranoga odgoja i obrazovanja odraslih budući da se u toj posljednjoj fazi najviše obrazovanjem odraslih sustavno rješavao problem nepismenosti. Stopa nepismenosti osoba starijih od 10 godina od 1971., kada je iznosila $8,95 \%$, spuštena je 1981 . na $5,6 \%{ }^{77}$

\section{Zaključak}

Nepismenost stanovništva u Hrvatskoj bila je dugotrajni problem koji su u prošlosti pokušali riješiti razni sustavi, ponajviše brojnim reformama školstva. Smanjivanje nepismenosti značilo je i borbu za modernizaciju društva te je svakako bilo jedan od mjeritelja razvoja. Visoki udio nepismenoga stanovništva naslijedila je i poslijeratna Jugoslavija. Nepismenost će se tako iskorjenjivati sve do 1980-ih.

Budući da se borba protiv nepismenosti prilagođavala zatečenoj situaciji, tijekom vremena poprimala je različite oblike i prioritete. U ovom je radu poseban naglasak bio na suzbijanju nepismenosti odraslih. Pritom treba naglasiti razliku između pojmova nepismenost i polupismenost. Nepismenost je obuhvaćala sve one koji su bez ikakve školske spreme, a polupismenost one koji imaju jedan do tri razreda osnovne škole. Po svršetku Drugoga svjetskog rata omasovljuje se i širi mreža analfabetskih tečajeva te produžnih tečajeva, narodnih knjižnica, čitaonica, narodnih sveučilišta. Osnivaju se kulturno-prosvjetna društva, a od početka šezdesetih godina XX. stoljeća tzv. narodno prosvjećivanje prerasta u posebno područje društvene brige za obrazovanje odraslih. Autori su, proučavajući izvore i smještajući ih u društveno-politički kontekst, detektirali tri faze borbe protiv nepismenosti nakon 1945. godine.

Prva je faza trajala od 1945. do 1950-ih. Započela je donošenjem Zakona o obaveznom sedmogodišnjem školovanju, a posebna pozornost posvećena je i pitanju nepismenosti. Krajem prve faze (1949.) održan je 3. plenum KPJ, koji je potvrdio potrebu uvođenja samoupravljanja u odgojno-obrazovni sustav i najavio postupno uvođenje osmogodišnjega školovanja. Održavali su se sustavni tečajevi opismenjavanja odraslih osoba. Takve akcije bile su izvrstan propagandni materijal jer se često naglašavalo da su široke akcije opismenjavanja bile jedan od najvećih kulturnih dometa. Zakonski temelji trebali su osigurati dugoročnu strategiju kroz školski sustav, a akcije opismenjavanja rješavati zatečenu situaciju. Opismenjavanje odraslih, a zatim i doškolovanje bilo je prioritetno zbog nedostatka kvalificirane radne snage, ali i stvaranja

UJAKOVIĆ, $A B C$ za odrasle, 47.

77 HR-HDA-1416-ZPPS SRH, kut. 20, spis br. 2/5-392-1974. 
slike o radništvu kao temeljnoj društvenoj skupini jedne socijalističke države s konačnim ciljem općekulturnoga uzdizanja.

Od samoga početka planove o opismenjavanju razrađivalo je Ministarstvo prosvjete potpomognuto sindikatima. Početni društveni problemi vidljivi su i u nedostatku kadra koji je trebao voditi tečajeve, pa su u prvim fazama organizirani i tečajevi za poučavatelje. I sami pojedinci koje su tečajevi opismenjavanja trebali zahvatiti nisu odmah tome lako i ozbiljno pristupili jer je zabilježen veliki problem s redovitim pohađanjem. S druge strane te akcije nisu odmah obuhvatile sve stanovništvo te su se najviše zadržavale u gradovima, a ruralno stanovništvo bilo je najslabije obuhvaćeno. Kako su se dalje oblikovale druga i treća faza, tako je organizacija i struktura borbe protiv nepismenosti postajala specifičnija.

To je vidljivo od druge faze, tijekom pedesetih i šezdesetih godina, kada se problemu opismenjavanja i obrazovanja odraslih pristupa sistematičnije, definiranjem osnovnoga obrazovanja odraslih. Osnivaju se škole za kvalificirane radnike, škole za stručni kadar, tehničke i druge stručne škole, kao i škole za visokokvalificirane radnike, a redovito rade u večernjim satima. Poseban je naglasak stavljen i na tzv. školsko-tvorničke centre, koji su provodili organizirano obrazovanje radnika uz rad u privrednim organizacijama i tvorničkim poduzećima. U tom razdoblju afirmacije samoupravnoga socijalizma i škole su se proglasile samoupravnom radnom organizacijom od posebne društvene važnosti. No i dalje je postojao problem nedostatka stručnoga kadra za opismenjavanje i obrazovanje odraslih.

Nedovoljna uključenost sustava obrazovanja odraslih u školski sustav općenito označila je prioritet treće faze borbe protiv nepismenosti tijekom sedamdesetih godina s ciljem potpune likvidacije nepismenosti. Prosvjetni savjet Hrvatske osnovao je 1974. Komisiju za borbu protiv nepismenosti. Komisija je radila na programu opismenjavanja i osnovnoga obrazovanja odraslih. U posljednjoj je fazi cilj bio viši stupanj opismenjavanja koji odgovara definiciji funkcionalne pismenosti, što je podrazumijevalo da se osoba može aktivno uključiti u sve radnje u kojima je pismenost potrebna za učinkovito funkcioniranje njegove zajednice.

Vrhunac organiziranoga odgoja i obrazovanja odraslih bio je u šezdesetima i sedamdesetima jer se obrazovanjem odraslih pomoću definiranih akcija sustavno rješavao problem nepismenosti. Sam proces borbe protiv nepismenosti i neobrazovanosti trajao je desetljećima, a krajni cilj nije potpuno ostvaren. 


\section{Arhivski izvori}

HR-HDA-1286-SSJ VSSH: Hrvatska, Hrvatski državni arhiv, Zagreb, fond 1286, Savez sindikata Jugoslavije. Vijeće Saveza sindikata Hrvatske.

HR-HDA-1416-ZPPS SRH: Hrvatska, Hrvatski državni arhiv, Zagreb, fond 1416, Zavod za prosvjetno-pedagošku službu Socijalističke Republike Hrvatske. Prosvjetni savjet - Komisija savjeta.

\section{Objavljeni izvori i tisak}

Glas rada (Zagreb), 1945-1949.

Prosvjetni vjesnik (Zagreb), 1958.

Radnik i obrazovanje (Zagreb), 1961.

Službeni list FNRJ (Beograd), 1947.

Ustav SFRJ, travanj 1963. Pristup ostvaren 4. 7. 2020. http://www.arhivyu.gov.rs/active/srlatin/home/glavna_navigacija/leksikon_jugoslavije/konstitutivni_akti_jugoslavije/ustav_sfrj_1963.html.

Ustav SFRJ, veljača 1974. Pristup ostvaren 4. 7. 2020. http://www.arhivyu.gov.rs/active/srlatin/home/glavna_navigacija/leksikon_jugoslavije/konstitutivni_akti_jugoslavije/ustav_sfrj_1974.html.

ZEČEVIĆ, Miodrag; LEKIĆ, Bogdan, ur. Privredna politika Vlade FNRJ. Zapisnici Privrednog saveta Vlade FNRJ, 1944-1953., knj. 1. Beograd: Arhiv Jugoslavije, 1995.

\section{Literatura}

BILANDŽIĆ, Dušan. Hrvatska moderna povijest. Zagreb: Golden marketing, 1999.

DIJANOŠIĆ, Branko. „Funkcionalna pismenost polaznika osnovnog obrazovanja odraslih od trećeg do šestog obrazovnog razdoblja”. Andragoški glasnik 16 (2012), br. 1: 21-31.

ĐORĐEVIĆ, Jovan; POTKONJAK, Nikola. Pedagogija. Beograd: Naučna knjiga, 1988.

FRANKOVIĆ, Dragutin. Povijest školstva i pedagogije u Hrvatskoj. Zagreb: Pedagoško-književni zbor, 1958.

HEĐBELI, Živana; MOKROVIĆ, Nikola. „Pregled uprave u Hrvatskoj od 1945. do 1990. godine”. U: Tehnični in vsebinski problemi klasičnega in elektronskega arhiviranja. Materialno varstvo arhivskega gradiva [Elektronski vir]. Zbornik mednarodne konference (Radenci, 15. - 17. april 2015), ur. Nina Gostenčnik. Maribor: Pokrajinski arhiv Maribor, 2015. Pristup ostvaren 28. 6. 2020. http://www.pokarhmb.si/uploaded/datoteke/Radenci/radenci2015/207222_hedzbeli_2015.pdf. 
LEČEK, Suzana. „Suradnja HKD Napredak i Seljačke sloge u kampanji opismenjivanja”. Časopis za suvremenu povijest 36 (2004), br. 3: 1101-1126.

OBAD, Željko. „Nakladništvo kao dio obrazovanja odraslih”. Andragoški glasnik 22 (2018), br. 1: 1-62.

OGRIZOVIĆ, Mihajlo. „Školstvo i prosvjeta u Hrvatskoj u jesen 1944. i u 1945. godini”. Zbornik Zavoda za povijesne znanosti Istraživačkog centra Jugoslavenske akademije znanosti i umjetnosti 11 (1981): 233-288.

PASTUOVIĆ, Nikola. „Uloga Pučkog otvorenog učilišta Zagreb u razvoju obrazovanja odraslih u Hrvatskoj”. Andragoški glasnik 22 (2018), br. 1 (37): 9-15.

PETRANOVIĆ, Branko. „Osnivački kongres Narodnog fronta Jugoslavije”. Časopis za suvremenu povijest 12 (1980), br. 1: 5-15.

PETRANOVIĆ, Branko. Politička i ekonomska osnova narodne vlasti u Jugoslaviji za vreme obnove. Beograd: Institut za savremenu istoriju, 1969.

PODREBAC, Vladimir. Socijalistički samoupravni preobražaj odgoja i obrazovanja u SR Hrvatskoj: 1974-1984. Zagreb: Školske novine, 1985.

POTKONJAK, Nikola M. Kuda ide srednje obrazovanje. Sarajevo; Beograd: Svjetlost; Zavod za udžbenike i nastavna sredstva, 1989.

POTKONJAK, Nikola M. Sistem obrazovanja i vaspitanja u Jugoslaviji. Beograd: Zavod za udžbenike i nastavna sredstva, 1980.

RADELIĆ, Zdenko. Hrvatska u Jugoslaviji 1945. - 1991. Od zajedništva do razlaza. Zagreb: Školska knjiga; Hrvatski institut za povijest, 2006.

RADELIĆ, Zdenko. Sindikat i radništvo u Hrvatskoj 1945. - 1950. Zagreb: Hrvatski institut za povijest, 2012.

SELINIĆ, Slobodan. „Počeci socijalističkog Novog Beograda”. Tokovi istorije (2007), br. 4: 75-96.

SPEHNJAK, Katarina. Javnost i propaganda. Narodna fronta u politici i kulturi Hrvatske 1945. - 1952. Zagreb: Hrvatski institut za povijest; Dom i svijet, 2002.

STIPETIĆ, Vladimir. „Pismenost i razvoj. Jedno stoljeće u eliminaciji nepismenosti na teritoriju SR Hrvatske (1880-1981)”. Naše teme 28 (1984), br. 11: 2455-2489.

ŠUVAR, Stipe. Škola i tvornica. U susret reformi odgoja i obrazovanja. Zagreb: Školska knjiga, 1977.

UJAKOVIĆ, Branka. ABC za odrasle. Opismenjavanje odraslih u 20. stoljeću. Zagreb: Hrvatski školski muzej, 2005.

VELČIĆ, Veseljko; MARKOVIĆ, Veljko; VELČIĆ, Vlado. Radničko sveučilište u obrazovanju kadrova iz privrede. Zagreb: Radničko sveučilište „Moša Pijade”, 1964.

ZANINOVIĆ, Mate. Opća povijest pedagogije. Zagreb: Školska knjiga, 1988. 


\section{SUMMARY}

\section{Action Plans to Combat in Croatia from 1945 to the 1970 s}

In the context of the political, economic, and social changes in the mid$20^{\text {th }}$ century, a systematic implementation of the core goals of the Communist Party of Yugoslavia/ League of Communists of Yugoslavia was conducted on all levels, resulting in structural changes in society. Among other things, these changes were the result of the measures implemented in order to reduce the number of illiterates, and this was directly related to the need to resolve basic social and economic problems.

In this paper, the authors examine the struggle against illiteracy in Croatia after World War II. The literacy action plans that were systematically conducted by state authorities indicate that the image of society underwent profound changes. Thus, from a bottom-up perspective, society became subject to long-lasting changes. With certain exceptions, educational topics and the history of education in the $20^{\text {th }}$ century remain unresearched in Croatian historiography, especially when compared to, say, the same topics in the $19^{\text {th }}$ century. Therefore, this topic represents a new beginning in research and, due to its nature, also enters the frame of social history in the second half of the 20th century.

Through source and literature analysis, the authors have determined three phases of educational changes. This paper shall examine the problem of combating illiteracy through changes in the educational system and literacy action plans in the period from 1945 to 1974, when the decision to form the Commission for Combatting Illiteracy was made.

The aim of this paper and this approach to the topic and problem of illiteracy through literacy action plans is to contribute to history of education research in Croatian historiography.

Key words: Croatia; $20^{\text {th }}$ century; socialism; illiteracy; literacy programmes; educational system 